\title{
Capital Structure and Speed of Adjustment in U.S. Firms. A Comparative Study in Microeconomic and Macroeconomic Conditions-A Quantile Regression Approach
}

\author{
Andreas Kaloudis ${ }^{1}$, Dimitrios Tsolis ${ }^{2}$ \\ ${ }^{1}$ PhD Candidate, Cultural Heritage and New Technologies Department, University of Patras, Greece \\ ${ }^{2}$ Assistant Professor, Cultural Heritage and New Technologies Department, University of Patras, Greece \\ Correspondence: Andreas Kaloudis, PhD Candidate, Cultural Heritage and New Technologies Department, \\ University of Patras, Greece.
}

Received: November 21, 2018

Accepted: September 12, 2019

Online Published: September 26, 2019

doi:10.5539/ibr.v12n10p98

URL: https://doi.org/10.5539/ibr.v12n10p98

\begin{abstract}
The major perspective of this paper is to provide more evidence regarding how "quickly", in different macroeconomic states, firms adjust their capital structure to their leverage targets. This study extends the empirical research on the topic of capital structure by focusing on a quantile regression model to investigate the behavior of firm-specific and macroeconomic factors across all quantiles of distribution of leverage (book leverage and market leverage). Therefore, depending on a partial adjustment model, we find that the adjustment speed fluctuated in different stages of book versus market leverage. Furthermore, while macroeconomic states change, we detect clear differentiations of the contribution and the effects of the firm-specific and the macroeconomic variables between market leverage and book leverage debt ratios. Consequently, we deduce that across different macroeconomic states the nature and maturity of borrowing influence the persistence and endurance of the relation between determinants and borrowing.
\end{abstract}

Keywords: capital structure, quantile regression, macroeconomy, firm characteristics, econometry, total debt, U.S., panel data, hausman test, fixed effects model, unbalanced sample

\section{Introduction}

Plausible questions have been triggered in the scientific area of capital structure dynamic determination prompted by the recent global financial crisis, regarding how "quickly", in different macroeconomic states, companies adjust their capital structure to their book leverage targets. In an effort to broaden the debate scope, we focus on SMEs and discuss the relative importance of macroeconomic and firm-specific variables, in changing macroeconomic conditions. Therefore, depending on a partial adjustment model, we obtain that book and market debt follow different patterns concerning their adjustment speeds. A scientific area that has drawn research interest during the last two decades is capital structure determination of Small and Medium Enterprises (SMEs) and the reason is partly the recognition of the importance of SMEs for the economy in terms of employment and value added as well as numbers of enterprises and partly the acknowledgement that SMEs financing exhibits considerable differences compared to large enterprises. Hence, during the last twenty years, a series of research has emerged which focuses on investigating the particularities of small enterprises in their capital structure determination. Particularly, this issue is tackled in Torres and Julien (2005) research from a managerial perspective, where they describe the main findings of researchers over the last three decades, which have led to the recognition of SMEs specificities. Thus, in this wide recognition where research has shed light on the fact that large firms' theory has limited applicability to SMEs, the theory of capital structure cannot be an exemption. Ang (1991) was the first that highlighted this approach by pointing out that the theory of finance was not developed with the small business in mind, whereas Cressy and Olofsson (1997) declare that small businesses are not scaled-down versions of large businesses and Michaelas et al. (1999) endeavors to relate the different theoretical attributes to small enterprises. On the contrary, in his research Hackbarth et al. (2006) indicated that little attention has been paid to the macroeconomic conditions' effects on capital structure choices and credit risk, notwithstanding the substantial development of the capital structure literature. Plausible questions have been triggered in the scientific area of capital structure determination by the recent global financial crisis 
regarding how quickly firms tend to adjust their capital structure in different economic states to their long-term targets. Furthermore, the research of Cook and Tang (2010) is built on the findings of previous analysts, such as Chloe et al. 1993; Gertler and Gilchrist, 1993; Korajczyk and Levy, 2003, where macroeconomic conditions do affect companies' financing choices, and denote that companies adjust their leverage toward target faster in good macroeconomic states compared to bad macroeconomic states. In their study, Oztekin and Flannery (2012) compare speed adjustments of capital structure across countries and prove that financial and legal conditions vary with debt adjustment speeds. Correspondingly, Baum et al. (2016) in his research follow a similar approach and indicate that companies with above-target leverage and financial surpluses adjust their leverage more rapidly when macroeconomic risk is high and firm-specific risk is low, whilst companies with below-target leverage and financial deficits adjust their capital structure more quickly when both types of risk are low. The context of Baum et al. (2016) triggers precisely the main idea of this paper, namely to investigate in changing macroeconomic states the relative significance of traditional firm-specific capital structure determinants, such as asset structure, size, profitability, risk and growth, versus macroeconomic variables. Contributing to the interesting debate of the relative importance of firm-specific versus macroeconomic variables in changing macroeconomic conditions is the main research objective of this paper, observed respectively in a demand-driven context vs. supply-driven context, in the SMEs environment while none of the aforementioned studies combine simultaneously SMEs' specificities with adjustment speed in capital structure determination or explore the issue of firm-specific vs. macroeconomic variables in different economic states. Two periods of different macroeconomic states are identified, growth and recession, that mainly follow the methodological explanation of Cook and Tang (2010) and Oztekin and Flannery (2012), by using a dynamic model of partial adjustment capital structure with unobserved heterogeneity and fake variable for the macroeconomic states. We find that there are clear differentiations of the effects and the contribution of the firm-specific versus the macroeconomic variables between long-term and short-term debt ratios in changing macroeconomic states. From our results we reach a conclusion that the nature and maturity of borrowing across different macroeconomic states affects the endurance and persistence of the relation between determinants and borrowing. Thus, our opinion is that this paper contributes on the recent dynamic determination of capital structure in the below ways. Firstly, we manage to broaden the scope of the debate by including SMEs, secondly, we show that macroeconomic states have a prevailing effect on how the relationships of capital structure determinants and leverage are shaped and finally we indicate that these relationships are also influenced by debt maturity.

\section{Method}

Initially, we probe if our panel data model is a random or fixed effect model. This can be detected through Hausman (1978) test, which allows us to find that our model is a fixed effect model. Generally, panel data models provide us control of the implications of companies' non-observable individual effects on the estimated parameters. To the extent of our knowledge panel data are the most appropriate to examine a dynamic phenomenon which varies across time compared to cross-section or time series data that neither express dynamic relations. Moreover, panel data allow us to estimate raised accuracy since they use double observations which are used in both assessment with the cross section or time series data.

\subsection{The Model}

Following the rationale of Cook and Tang (2010), Oztekin and Flannery (2012), Nikolaos Daskalakis, Dimitrios Balios and Violetta Dalla (2017), Andreas Kaloudis and Dimitrios Tsolis (2018), we use a partial adjustment model, which assumes that the target debt ratio $\mathrm{LEV}$ * $_{\mathrm{i}, \mathrm{t}}$ from firm $\mathrm{i}$ at time $\mathrm{t}$, is given by:

$$
\begin{aligned}
& \text { LEVB } *_{\mathrm{i}, \mathrm{t}}=a *+a *_{\mathrm{i}}+\beta * X_{\mathrm{i}, \mathrm{t}}+\gamma * M_{\mathrm{t},} \quad i=1_{w \ldots \ldots, N} \quad t=2, \ldots \ldots, T_{\mathrm{i}} \\
& L E V M *_{\mathrm{i}, \mathrm{t}}=a *+a *_{\mathrm{i}}+\beta * X_{\mathrm{i}, \mathrm{t}}+\gamma * M_{\mathrm{t}}, \quad i=1, \ldots \ldots, N, \quad t=2, \ldots \ldots T_{\mathrm{i}}
\end{aligned}
$$

Where $\mathbf{a} *$ is the constant term, $\mathbf{a} * *_{\mathrm{i}}$ is the unobserved heterogeneity of firm $\tilde{1}_{3} \mathrm{X}=\left(\mathrm{X}_{1}, \ldots, \mathrm{X}_{\mathrm{K}}\right)^{\prime}$ and $\mathrm{M}=\left(\mathrm{M}_{1, \ldots,} \mathrm{M}_{\mathrm{I}}\right)^{n}$ are (column) vectors of firm specific and macroeconomic variables respectively, $\beta *=\left(\beta *_{1}, \ldots, \beta *_{\mathrm{K}}\right)$ is the (row) coefficient vector of firm-specific variables and $\gamma *=\left(\gamma *_{1} \ldots \ldots, \gamma *_{\mathrm{j}}\right)$ the (row) 
coefficient of the macroeconomic variables. The debt ratio $\mathrm{DR}_{\mathrm{i}, t}$ adjust to its target according to the rule:

$$
\begin{aligned}
& D R_{\mathrm{i}_{i}, \mathrm{t}}-D R_{\mathrm{i}, \mathrm{t}-1}=\delta *\left(D R *_{\mathrm{i}, \mathrm{t}}-D R_{\mathrm{i}, \mathrm{t}-1}\right)+\varepsilon_{\mathrm{i}, \mathrm{t}} \\
& L E V B_{i_{j}, t}-L E V B_{i_{j} t-1}=\delta *\left(L E V B *_{i, t}-L E V B_{i, t-1}\right)+\varepsilon_{i, t} \\
& L E V M_{i_{i}, t}-L E V M_{i_{i, t}-1}=\delta *\left(L E V M *_{i, t}-L E V M_{i, t-1}\right)+\varepsilon_{i, t}
\end{aligned}
$$

Where $\delta *$, is the speed of adjustment and $\varepsilon_{\mathrm{it} t}$ is the error term.

\subsection{The Data}

The data are collected from published financial statements of U.S. economy companies for 44 years. We use a dataset of SME's and MNC's of United States economy. For the best of our knowledge panel data are the most appropriate to observe a dynamic phenomenon that variates cross time in comparison with cross-section and time series data which do not express dynamic relations and produced estimates are highly accurate due to the multicollinearity existence. Furthermore, panel data provide us estimates of raised accuracy while they use more than the double number of total observations that is used in both assessment with the times series and cross section data.

\subsection{The Variables}

\subsubsection{Proxies for Leverage}

Book leverage is the ratio of book debt/total assets.

Market leverage is the ratio of book debt / ( book debt + market equity )

\subsubsection{Firm Specific Factors}

Liquidity (LIQTA) is the ratio of current assets to current liabilities, as used by Graham and Harvey (2001) and De Jong et al. (2008).

Ndts is the nondebt tax shields (tax shields excluding interest), as used by Titman and Wessels (1998), Barton et al. (1989), Prowse (1990) and Miguel and Pindado (2001), who found an inverse relationship between leverage and non-debt tax shields;

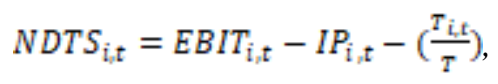

Where $\mathbb{I P}_{\mathrm{i}, \mathrm{t}}$ is the interest payable, $\mathrm{T}_{\mathrm{i}, \mathrm{t}}$ is the income Tax and $\mathrm{T}$ is the corporate tax rate.

Profitability (PROFTA). In view of the pecking order theory, firm's financing decisions follow in general a hierarchy, preferring debt over equity and internal over external financing (Michaelas et al., 1999, Daskalakis \& Psillaki, 2008; Psillaki \& Daskalakis, 2009). Thus, it is expected that profitability should be negatively related to debt and be measured as earnings before interest and taxes to total assets.

Size (SIZEAT), expected to be positively correlated with debt levels. Larger firms may be able to reduce the transaction costs associated with long-term debt issuance. Public corporate debt usually trades in large blocks relative to the size of an equity trade, and most issues are at least 100 million dollars in face value to provide liquidity. Marsh's (1982) survey concludes that large firms more often choose long-term debt while small firms choose short-term debt. Size is measured as the natural logarithm of total sales.

Growth (GROWTHAT) and leverage relation can be either negative or positive, with GR being measured as the annual rate of change in sales.

Investments (INVTA) In accordance with Lewellen and Badrinath (1997), 


$$
I_{\mathrm{i}, \mathrm{t}}=N P P E_{\mathrm{i}, \mathrm{t}}-N P P E_{\mathrm{i}, \mathrm{t}-1}+D_{\mathrm{i}, \mathrm{t}},
$$

where $\mathrm{NPPE}_{\mathrm{i}, \mathrm{t}}$ is the fixed assets and $\mathrm{D}_{\mathrm{i}, \mathrm{t}}$ is a proxy for the depreciation.

The market-to-book (MRBRATIO) ratio was used by Rajan and Zingales (1995), De Jong et al.

(2008), Lemmon and Zender (2010) and Sinan (2010).

\subsubsection{Macroeconomic Factors}

Inflation: An extensively investigated macroeconomic factor is the inflation rate (INFL). However, contradictory evidence exists concerning the effect of inflation on capital structure. In the context of literature, Bastos et al., (2009) found no effect of inflation on leverage, while Frank \& Goyal (2009) detected a positive relationship between market leverage and inflation, yet no relationship on book leverage. On the other hand, Hanousek \& Shyamshur (2011) verified that inflation generally has a positive influence on leverage, this effect however turns unimportant for certain specifications of their model. INFL is referred to the annual rate of change of the CPI index. Gdp_Rate: GDP growth indicates monetary conditions in general. Beck et al. (2008), De Jong et al. (2008), Chipeta \& Mbululu (2013) and Muthama et al. (2013) discovered that firms that operate in a country with increased real GDP, have a higher level of economic wealth and therefore they tend to issue more debt than equity. On the other hand, Kayo \& Kimura (2011) confirmed a negative relationship and argued that companies tend to generate higher net incomes and greater revenues during periods of peak economic activity. In view of this, the opportunity to finance further investments internally and not by issuing equity or debt is provided.

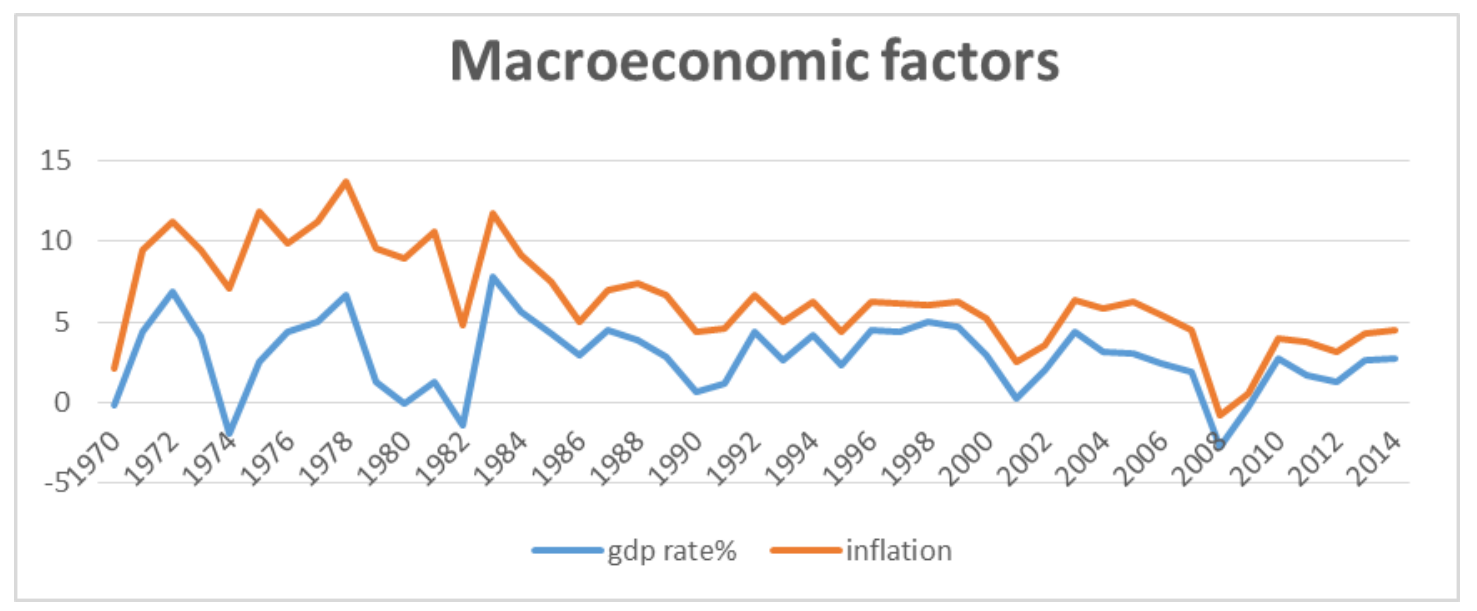

\subsection{The Estimation Methodology}

The Quantile regression in Panel Data approach

Our approach is based on quantile regressions, which estimate the effect of explanatory variables on the dependent variable at different points of the dependent variable's conditional distribution. Quantile regressions were originally presented as a 'robust' regression method which permits for estimation where the typical hypothesis of normality of the error term might not be strictly satisfied (Koenker and Bassett, 1978); This method has also been used to estimate models with censoring (Powell, 1984, 1986; Buchinsky, 1994, 1995). Recently, quantile regressions have been used simply to get evidence about points in the distribution of the dependent variable further than the conditional mean (Buchinsky, 1994, 1995; Eide and Showalter, 1997). We use quantile regressions to observe whether the effects of factors are differentiated across the 'quantiles' in the conditional distribution of dependent variable. As described by Koenker and Bassett (1978), the estimation is done by minimizing

$$
\operatorname{Min}_{\beta \in R^{K}} \sum_{t \in\left\{t: y_{t} \geq x_{t} \beta\right.} \theta\left|y_{t}-\mathrm{x}_{\mathrm{t}} \beta\right|+\sum_{\mathrm{t} \in\left[\mathrm{t} \mathrm{y}_{\mathrm{t}}<\mathrm{x}_{\mathrm{t}} \beta\right]^{\prime}}(1-\theta)\left|\mathrm{y}_{\mathrm{t}}-\mathrm{x}_{\mathrm{t}} \beta\right|
$$

where $y t$, is the dependent variable, $x t$ is the $\mathrm{k}$ by 1 vector of explanatory variables, $\beta$ is the coefficient vector 
and $\Theta$ is the estimated quantile. The coefficient vector $b$ will differ depending on the particular estimated quantile.

\section{Results}

We choose to use the conditional quantile estimator over the OLS estimator which focuses only on the central tendency of the distribution and does not permit the possibility of differentiation of the explanatory variables impact for highly leveraged firms. An additional reason for choosing the conditional quantile estimator is that it provides us the possibility to observe the sign and probability fluctuations across quantiles, from the lower leveraged firms to the higher leveraged firms.

Table 1. Mean variables

\begin{tabular}{|c|c|c|c|c|c|c|c|c|}
\hline & |LEVB & NDTSTA & GROWTHT & INVTTA & PROFITABIL & SIZETOTAI & LIQTA & MBRATIO \\
\hline FYEAR & Mean & & & & & & & \\
\hline 1970 & 0.139690 & 0.042600 & 0.059778 & 0.244027 & -0.000260 & 0.132120 & 0.352779 & \begin{tabular}{|l|}
.535749 \\
\end{tabular} \\
\hline 1971 & 0.141780 & 0.046729 & 0.101896 & 0.240493 & 0.004645 & 0.127837 & 0.313398 & 1.698977 \\
\hline 1972 & 0.140992 & 0.062088 & 0.129515 & 0.242241 & 0.005716 & 0.117787 & 0.250915 & 1.678525 \\
\hline 1973 & 0.143063 & 0.071237 & 0.076835 & 0.253919 & 0.015958 & 0.113954 & 0.344997 & 1.210098 \\
\hline 1974 & 0.147631 & 0.024458 & -0.011965 & 0.254273 & -0.000533 & -0.003149 & 0.949054 & 0.941828 \\
\hline 1975 & 0.150708 & 0.039875 & 0.041785 & 0.239150 & -0.025303 & -0.027838 & 0.785016 & 1.066874 \\
\hline 1976 & 0.147880 & 0.051400 & -0.037588 & 0.236601 & -0.033367 & -0.093113 & 1.172402 & 1.148631 \\
\hline 1977 & 0.150343 & -0.037280 & -0.240755 & 0.235098 & -0.260143 & -0.139904 & 1.182724 & 1.200959 \\
\hline 1978 & 0.154564 & -0.105562 & 0.053530 & 0.230952 & -18.46424 & -0.368005 & 1.124757 & 1.266096 \\
\hline 1979 & 0.153878 & 0.053043 & -0.249024 & 0.230988 & -0.308044 & -0.212858 & 1.305583 & 1.522321 \\
\hline 1980 & 0.149778 & -0.018428 & 0.046461 & 0.218302 & -12.11516 & -0.775996 & 1.396896 & 1.978820 \\
\hline 1981 & 0.142240 & -0.007546 & -0.048861 & 0.208034 & -16.18303 & -0.667680 & 1.365316 & 1.706371 \\
\hline 1982 & 0.144690 & -0.070614 & -0.065758 & 0.195780 & -21.28464 & -0.192868 & 1.604093 & 1.945591 \\
\hline 1983 & 0.133584 & -0.145602 & -0.045320 & 0.186151 & -64.82011 & -1.426612 & 1.261924 & 3.917737 \\
\hline 1984 & 0.134885 & -0.151592 & -0.429925 & 0.190624 & -1.775894 & -0.083775 & 1.320738 & 2.127915 \\
\hline 1985 & 0.137273 & -0.411265 & -0.093992 & 0.179714 & -220.3048 & -0.405008 & 1.790088 & 2.496286 \\
\hline 1986 & 0.137903 & -0.245351 & -0.829047 & 0.173315 & -45.67793 & -0.780753 & 1.648475 & 4.925750 \\
\hline 1987 & 0.140365 & -0.313044 & -0.082686 & 0.170558 & -2.311457 & -0.620398 & 1.595128 & 2.793230 \\
\hline 1988 & 0.142941 & -0.090066 & -0.338502 & 0.171510 & -20.48788 & -1.888683 & 1.098588 & 2.021181 \\
\hline 1989 & 0.146296 & -0.090016 & -0.607975 & 0.167783 & -13.52642 & -2.112387 & 1.392790 & 2.036429 \\
\hline 1990 & 0.143482 & -0.456505 & -1.964750 & 0.165067 & -56.16537 & -1.679670 & 1.031316 & 1.954070 \\
\hline 1991 & 0.137889 & 0.061399 & -0.900192 & 0.159298 & -183.4780 & -0.955596 & 1.306244 & 2.362401 \\
\hline 1992 & 0.133088 & -0.212463 & -0.219172 & 0.156648 & -16.69850 & -1.242420 & 0.948451 & 2.367913 \\
\hline 1993 & 0.128893 & 0.026244 & -0.036134 & 0.152011 & -85.29508 & -1.080205 & 0.874290 & 2.345391 \\
\hline 1994 & 0.129322 & -0.183577 & -0.036700 & 0.149810 & -25.78515 & -0.111067 & 0.766826 & 2.122566 \\
\hline 1995 & 0.131387 & -0.207771 & 0.046239 & 0.145471 & -72.40709 & -0.904528 & 0.585123 & 4.207664 \\
\hline 1996 & 0.126173 & -0.310088 & -0.028548 & 0.139830 & -34.82157 & -0.208535 & 0.505412 & 4.230933 \\
\hline 1997 & 0.129461 & -0.198543 & -0.328197 & 0.134392 & -12.85966 & -0.145216 & 0.506757 & 3.897723 \\
\hline 1998 & 0.133354 & -0.393308 & -0.241248 & 0.125057 & -28.11937 & -0.300919 & 0.675374 & 3.914247 \\
\hline 1999 & 0.133423 & -0.661480 & -0.240152 & 0.116419 & -144.4903 & -0.650102 & 1.108602 & 7.777139 \\
\hline 2000 & 0.129199 & -0.896225 & -0.714099 & 0.113977 & -166.5361 & -2.813891 & 2.113655 & 11.63617 \\
\hline 2001 & 0.130926 & -2.153007 & -2.235403 & 0.109943 & -533.4581 & -3.121916 & 2.117576 & 45.65303 \\
\hline 2002 & 0.129775 & -7.194115 & -1.420282 & 0.108124 & -3945.040 & -2.407512 & 1.417264 & 18.78382 \\
\hline 2003 & 0.127107 & -2.157808 & -0.554177 & 0.102899 & -769.3364 & -2.747282 & 1.372104 & 34.10847 \\
\hline 2004 & 0.122018 & -2.166352 & -0.474094 & 0.100291 & -757.6105 & -2.226387 & 1.026367 & 25.38208 \\
\hline 2005 & 0.119326 & -1.673168 & -3.844319 & 0.096758 & -498.8867 & -1.939739 & 0.941373 & 41.69120 \\
\hline 2006 & 0.117370 & -2.294531 & -19.49168 & 0.095849 & -560.5591 & -0.620489 & 1.065100 & 12.20908 \\
\hline 2007 & 0.117952 & -19.96244 & -0.675176 & 0.093070 & -810.5068 & -0.897278 & 1.147026 & 18.08759 \\
\hline 2008 & 0.124018 & -5.812493 & -1.501465 & 0.096243 & -431.6909 & -1.263041 & 0.851625 & 26.51975 \\
\hline 2009 & 0.119192 & -1.953972 & -0.306205 & 0.087959 & -537.0656 & -2.319693 & 1.425346 & 32.38875 \\
\hline 2010 & 0.112245 & -3.175418 & -0.149307 & 0.087225 & -506.5191 & -1.897800 & 1.560945 & 33.37853 \\
\hline 2011 & 0.114922 & -3.032119 & -0.651545 & 0.089214 & -1296.340 & -2.929817 & 1.318023 & 58.76859 \\
\hline 2012 & 0.118043 & -2.041775 & -1.169095 & 0.082447 & -533.9204 & -4.136806 & 1.471296 & 62.41736 \\
\hline 2013 & 0.122366 & -3.860906 & -1.184355 & 0.080221 & -980.9264 & -4.436785 & 1.711409 & 56.20476 \\
\hline 2014 & 0.128992 & -3.245300 & -1.007030 & 0.080156 & -459.4656 & -2.251242 & 1.019701 & 44.83848 \\
\hline All & 0.132945 & -1.582786 & & 0.149885 & -339.4475 & -1.218061 & 1.157826 & 15.33793 \\
\hline
\end{tabular}

Table 1 contains the timeless process of the mean value of the variables listed in descriptive statistics table. As can be seen, the profitability shows that the businesses are not stable and do not have the capacity, even before the crisis, to produce earnings on their spending. The negative average that appears from the beginning (1970) just shows the weaknesses and not the business expenditure audited. The book value leverage fluctuated at low 
levels from 1970 to 1982 and 1983 to 2004 and the bottomed values noticed from 2005 to 2012. The variable market-to-book ratio seems to reflect the true value of the business in the years 2001 to 2014. After 2005 the average price of the companies rises inexplicably, warning that the market value of a company is not its relative accounting value. The size and growth of US firms remain constant during all the years except 2012, which shows a negative trend from 1974 to 2014. The liquidity variable illustrates that the asset transactions do not affect the prices, which remain unaffected. According to the table, the variable investment is only affected by the crisis from 2005 until 2014. The tax shield non-interest seems to be used by US companies to reduce their taxes owed. This happens all over the years from 2001 to 2011.

Table 2. Correlation of variables

\begin{tabular}{|c|c|c|c|c|c|c|c|c|c|c|c|}
\hline $\begin{array}{l}\text { Correlation } \\
\text { Probability }\end{array}$ & LEVM & LEVB & NTDS AT & GROWTHAT & INVTA & PROFTA & SIZEAT & LIQTA & MBRATIO & INFLATION & GDP RATE \\
\hline LEVM & $\begin{array}{r}1.000000 \\
\ldots\end{array}$ & & & & & & & & & & \\
\hline LEVB & $\begin{array}{r}0.774976 \\
0.0000\end{array}$ & $\begin{array}{r}1.000000 \\
-.--\end{array}$ & & & & & & & & & \\
\hline NTDS_AT & $\begin{array}{r}0.004957 \\
0.0233\end{array}$ & $\begin{array}{r}-0.001813 \\
0.4067\end{array}$ & $\begin{array}{r}1.000000 \\
-\end{array}$ & & & & & & & & \\
\hline GROWTHAT & $\begin{array}{r}0.001258 \\
0.5648\end{array}$ & $\begin{array}{r}-0.016054 \\
0.0000\end{array}$ & $\begin{array}{r}0.287029 \\
0.0000\end{array}$ & $\begin{array}{r}1.000000 \\
-\cdots--\end{array}$ & & & & & & & \\
\hline INVTA & $\begin{array}{r}0.109086 \\
0.0000\end{array}$ & $\begin{array}{r}0.002776 \\
0.2039\end{array}$ & $\begin{array}{r}0.004726 \\
0.0305\end{array}$ & $\begin{array}{r}0.003584 \\
0.1009\end{array}$ & $\begin{array}{r}1.000000 \\
-.--\cdot\end{array}$ & & & & & & \\
\hline PROFTA & $\begin{array}{r}0.003712 \\
0.0893\end{array}$ & $\begin{array}{r}-0.005120 \\
0.0191\end{array}$ & $\begin{array}{r}0.701418 \\
0.0000\end{array}$ & $\begin{array}{r}0.575486 \\
0.0000\end{array}$ & $\begin{array}{r}0.005032 \\
0.0212\end{array}$ & $\begin{array}{r}1.000000 \\
\ldots---.\end{array}$ & & & & & \\
\hline SIZEAT & $\begin{array}{r}0.012493 \\
0.0000\end{array}$ & $\begin{array}{r}0.007104 \\
0.0011\end{array}$ & $\begin{array}{r}0.019446 \\
0.0000\end{array}$ & $\begin{array}{r}-0.108386 \\
0.0000\end{array}$ & $\begin{array}{r}0.017302 \\
0.0000\end{array}$ & $\begin{array}{r}-0.000960 \\
0.6603\end{array}$ & $\begin{array}{r}1.000000 \\
\ldots---\end{array}$ & & & & \\
\hline LIQTA & $\begin{array}{r}-0.033672 \\
0.0000\end{array}$ & $\begin{array}{r}-0.034693 \\
0.0000\end{array}$ & $\begin{array}{r}-0.000571 \\
0.7939\end{array}$ & $\begin{array}{r}-0.004025 \\
0.0654\end{array}$ & $\begin{array}{r}-0.023213 \\
0.0000\end{array}$ & $\begin{array}{r}-0.001450 \\
0.5069\end{array}$ & $\begin{array}{r}-0.024153 \\
0.0000\end{array}$ & $\begin{array}{r}1.000000 \\
\ldots\end{array}$ & & & \\
\hline MBRATIO & $\begin{array}{r}-0.019342 \\
0.0000\end{array}$ & $\begin{array}{r}-0.002551 \\
0.2430\end{array}$ & $\begin{array}{r}-0.527220 \\
0.0000\end{array}$ & $\begin{array}{r}-0.307033 \\
0.0000\end{array}$ & $\begin{array}{r}-0.015617 \\
0.0000\end{array}$ & $\begin{array}{r}-0.378144 \\
0.0000\end{array}$ & $\begin{array}{r}-0.364534 \\
0.0000\end{array}$ & $\begin{array}{r}0.010543 \\
0.0000\end{array}$ & $\begin{array}{r}1.000000 \\
-.---\end{array}$ & & \\
\hline INFLATION & $\begin{array}{r}0.203700 \\
0.0000\end{array}$ & $\begin{array}{r}0.079925 \\
0.0000\end{array}$ & $\begin{array}{r}0.004534 \\
0.0379\end{array}$ & $\begin{array}{r}0.001399 \\
0.5220\end{array}$ & $\begin{array}{r}0.263124 \\
0.0000\end{array}$ & $\begin{array}{r}0.002764 \\
0.2057\end{array}$ & $\begin{array}{r}0.009036 \\
0.0000\end{array}$ & $\begin{array}{r}0.004239 \\
0.0523\end{array}$ & $\begin{array}{r}-0.013508 \\
0.0000\end{array}$ & $\begin{array}{r}1.000000 \\
-\cdots--\end{array}$ & \\
\hline GDP_RATE_ & $\begin{array}{r}-0.022126 \\
0.0000\end{array}$ & $\begin{array}{r}0.013480 \\
0.0000\end{array}$ & $\begin{array}{r}0.006462 \\
0.0031\end{array}$ & $\begin{array}{r}0.001301 \\
0.5515\end{array}$ & $\begin{array}{r}0.059024 \\
0.0000\end{array}$ & $\begin{array}{r}0.001688 \\
0.4397\end{array}$ & $\begin{array}{r}0.005138 \\
0.0187\end{array}$ & $\begin{array}{r}-0.000371 \\
0.8653\end{array}$ & $\begin{array}{r}-0.008721 \\
0.0001\end{array}$ & $\begin{array}{r}-0.145853 \\
0.0000\end{array}$ & $\begin{array}{r}1.000000 \\
-\end{array}$ \\
\hline
\end{tabular}

Table 2 illustrates the correlation coefficients between the variables used in our model. The dependent and independent variables are provided with a Pearson correlation matrix. It is conspicuous that there is a non-statistically significant and negative correlation ( $\mathrm{r}=-0.001821)$ between leverage in book values and non-debt tax shields. Similar findings were obtained by Frank \& Goyal (2003). A statistically significant and positive correlation between leverage and investments at the 5\% significance level, a statistically negative correlation ( $\mathrm{r}=-0.0328)$ between leverage and liquidity at the 5\% significance level (Pecking order theory), a statistically significant and negative correlation $(\mathrm{r}=-0.034814)$ between leverage and profitability at the $5 \%$ significance level. Pecking-order theory predicts a negative relationship between profitability and leverage (accounting and market). This theory argues that companies will prefer to finance their needs first by using sustainable profits, then through borrowing and then through the issuance of new shares. According to the Pecking-order theory, companies that are rapidly developing and have high funding needs will move on to short-term funding that is less subject to asymmetric information. Furthermore, Pearson correlation provide us information for positive relation $(\mathrm{r}=0.0071)$ between leverage and size. This finding is in line with trade-off theory, that is, the bigger the business is, the greater the ability to borrow, and therefore it can have a higher leverage than a smaller company. According to Titman \& Wessels (1988), the bigger the business-diversity, the shorter the probability of bankruptcy will be, and the less volatility is observed in its cash flows, so it can borrow to a larger extent from smaller companies. Finally, there is a statistically significant and negative correlation $(\mathrm{r}=-0.0161)$ between leverage and growth at the 5\% significance level. Regarding trade-off theory, companies 
with high growth (investment) prospects must have low levels of borrowing.

Hausman Test

With the regression equation, we will choose the most catalyzed model between fixed effects and random effects and with the help of the Hausman test we will make the most appropriate choice for our model.

Correlated Random Effects - Hausman Test

Equation: RNDOM_LEVB

Test cross-section random effects

\begin{tabular}{llll}
\hline \hline Test Summary & $\begin{array}{l}\text { Chi-Sq. } \\
\text { Statistic }\end{array}$ & Chi-Sq. d.f. & Prob. \\
\hline \hline Cross-section random & 140.152192 & 7 & 0.0000 \\
\hline \hline
\end{tabular}

$\mathrm{H}_{0}$ : Random effects model is appropriate, $\mathrm{H}_{1}$ : Fixed effect model is appropriate.

Probability of Chi-Sq $<0.05$, so we reject null hypothesis, and Fixed Effect Model is the most appropriate for our model.

Table 3. Quantile Regression: LEVM $*_{\mathrm{i}, \mathrm{t}}=\mathrm{a} *+\mathrm{a} *{ }_{\mathrm{i}}+\beta * \mathrm{X}_{\mathrm{i}, \mathrm{t}}+\gamma * \mathrm{M}_{\mathrm{t}}$

\begin{tabular}{|c|c|c|c|c|c|}
\hline MARKET LEVERAGE & \multicolumn{5}{|c|}{ QUANTILES } \\
\hline & 0,15 & 0,35 & 0,5 & 0,75 & 0,95 \\
\hline LIQUIDITY & $-0,0005$ & $-0.0001^{* * *}$ & $-0.0001^{* * *}$ & $-0.0001^{* * *}$ & $-0.0001^{* * *}$ \\
\hline sterrors & 0.0003 & $4.53 \mathrm{E}-05$ & $4.95 \mathrm{E}-05$ & $1.84 \mathrm{E}-05$ & $1.62 \mathrm{E}-05$ \\
\hline MBRATIO & $-5.59 \mathrm{E}-06$ & $-1.38 \mathrm{E}-05^{* * *}$ & $-1.57 \mathrm{E}-05^{* * *}$ & $-1.76 \mathrm{E}-05^{* * *}$ & $-3.14 \mathrm{E}-05^{* * *}$ \\
\hline sterrors & $5.03 \mathrm{E}-06$ & $1.33 \mathrm{E}-06$ & $8.72 \mathrm{E}-07$ & $1.95 \mathrm{E}-06$ & $4.77 \mathrm{E}-07$ \\
\hline NDTS & $-5.16 \mathrm{E}-06$ & $-1.16 \mathrm{E}-05^{* * *}$ & $-1.25 \mathrm{E}-05^{* * *}$ & $-3.00 \mathrm{E}-05$ & $-5.11 \mathrm{E}-05^{* * *}$ \\
\hline sterrors & $5.09 \mathrm{E}-06$ & $1.37 \mathrm{E}-06$ & $9.00 \mathrm{E}-07$ & 0.0001 & $3.00 \mathrm{E}-06$ \\
\hline PROFITABILITY & $-1.21 \mathrm{E}-08$ & $-3.88 \mathrm{E}-08^{* * *}$ & $-4.89 \mathrm{E}-08^{* * *}$ & $-3.27 \mathrm{E}-08$ & $-8.45 \mathrm{E}-09$ \\
\hline sterrors & $8.09 \mathrm{E}-09$ & $2.76 \mathrm{E}-09$ & $1.84 \mathrm{E}-09$ & $3.61 \mathrm{E}-07$ & $5.53 \mathrm{E}-09$ \\
\hline SIZE & $-1.86 \mathrm{E}-06$ & $-1.08 \mathrm{E}-05^{* * *}$ & $-9.76 \mathrm{E}-06^{* * *}$ & $-1.60 \mathrm{E}-05^{* * *}$ & $-2.83 \mathrm{E}-05^{* * *}$ \\
\hline sterrors & $8.17 \mathrm{E}-06$ & $2.31 \mathrm{E}-06$ & $2.05 \mathrm{E}-06$ & $3.00 \mathrm{E}-06$ & $2.22 \mathrm{E}-06$ \\
\hline GROWTH & $-1.68 \mathrm{E}-06$ & $5.97 \mathrm{E}-06^{* * *}$ & $9.62 \mathrm{E}-06^{* * *}$ & $9.38 \mathrm{E}-06$ & $2.65 \mathrm{E}-06^{* * *}$ \\
\hline sterrors & $1.56 \mathrm{E}-06$ & $1.61 \mathrm{E}-06$ & $1.12 \mathrm{E}-06$ & $6.61 \mathrm{E}-05$ & $5.94 \mathrm{E}-07$ \\
\hline INVESTMENTS & $-0.0083^{* * *}$ & $-0.0145^{* * *}$ & $-0.0031^{* * *}$ & $0.0238^{* * *}$ & $0.0676^{* * *}$ \\
\hline sterrors & 0.0013 & 0.0014 & 0.0010 & 0.0016 & 0.0075 \\
\hline INFLATION & $0.0025^{* * *}$ & $0.0025^{* * *}$ & $0.0022^{* * *}$ & $0.0025^{* * *}$ & $-0.0042^{* * *}$ \\
\hline sterrors & $9.85 \mathrm{E}-05$ & 0.0001 & 0.0001 & 0.0001 & 0.0004 \\
\hline GDPRATE & $-0.0008^{* * *}$ & $-0.0026^{* * *}$ & $-0.0030^{* * *}$ & $-0.0047^{* * *}$ & $-0.0129^{* * *}$ \\
\hline sterrors & 0.0001 & $8.77 \mathrm{E}-05$ & $7.42 \mathrm{E}-05$ & 0.0001 & -0.012919 \\
\hline FIXED_EFFECTS & $0.4395^{* * *}$ & $0.8202^{* * *}$ & $0.9920^{* * *}$ & $1.2649^{* * *}$ & $1.2701^{* * *}$ \\
\hline R-squared & $11.1 \%$ & $34.8 \%$ & $44.6 \%$ & $50.2 \%$ & $42 \%$ \\
\hline
\end{tabular}

Assets structure variable (LAS) regarding total debt, enters with a positive sign (Bradley et al. (1984); Kaur\& Rao (2009)) and finally shifts to a negative sign (Nguyen \& Ramachandran (2006); Al- Ajmi et al. (2009); Karadeniz et al. (2009); Matzaz \&Dusan (2009); Sheikh \& Wang (2011)) from 0.6 quantile remaining statistically significant. The fact that SIZE (SIZE) enters with an insignificantly negative coefficient and from 0.35 quantile becomes significant with the same negative sign and rises since the 0.9 quantile of market leverage ratio, indicates that larger enterprises are less diversified and can be expected to bankrupt more often while 
smaller firms are usually opaquer well. At this point, larger firms can be expected for lower levels of leverage. Growth (LGR), enters with a negative sign and from 0.35 quantile becomes positive until the 0.9 quantile that is statistically significant for the total of quantiles. Firms with higher growth opportunities are more likely to exhaust internal funds and seek external financing. Profitability (Lprof), appears with a negative sign that is non-statistically significant and from 0.35 until 0.50 quantile the sign turns to negative and significant; a fact that indicates that higher total-leveraged firms in US, according to the Trade-off theory, are less profitable while less total-leveraged firms according Pecking order theory for financing decisions follow a preference for internal over external financing and for debt over equity. Tax considerations are very noticeable for enterprises because of the reason that they can produce high profit. Non-debt-tax-shields enter with negative and non-significant sign and remain negative and statistically significant. This suggests that the relative advantage of resorting to debt as a tax shield alternative to depreciation is lower for high levels of total leverage. Liquidity remains negative and significant. Cash-rich companies expected to have lower debt and they prefer internal financing (Pecking order theory). The fact that inflation (infl) starts with positive sign and from 0.95 quantile becomes negative, indicates that the high-leveraged firms are influenced from inflation in contrast to leveraged and less-leveraged firms, Frank and Goyal (2009).

Table 4. Quantile Regression: LEVB $*_{\mathrm{i}, \mathrm{t}}=\mathrm{a} *+\mathrm{a} * \mathrm{i}+\beta * \mathrm{X}_{\mathrm{i}, \mathrm{t}}+\gamma * \mathrm{M}_{\mathrm{t}}$,

\begin{tabular}{|c|c|c|c|c|c|}
\hline BOOK LEVERAGE & \multicolumn{5}{|c|}{ QUANTILES } \\
\hline & 0,15 & 0,35 & 0,5 & 0,75 & 0,95 \\
\hline LIQUIDITY & -0.0008 & $-0.0001^{* *}$ & $-0.0001^{* * *}$ & $-0.0002^{* * *}$ & $-0.0001^{* * *}$ \\
\hline sterrors & 0.0005 & $8.95 \mathrm{E}-05$ & $3.73 \mathrm{E}-05$ & $1.43 \mathrm{E}-05$ & $8.03 \mathrm{E}-06$ \\
\hline MBRATIO & $-1.92 \mathrm{E}-05^{* * *}$ & $-6.18 \mathrm{E}-06^{* * *}$ & $-4.17 \mathrm{E}-06^{* * *}$ & $-3.09 \mathrm{E}-06^{* * *}$ & 0.0006 \\
\hline sterrors & $5.37 \mathrm{E}-06$ & $7.46 \mathrm{E}-07$ & $3.90 \mathrm{E}-07$ & $7.50 \mathrm{E}-07$ & 0.0004 \\
\hline NDTS & $3.94 \mathrm{E}-05^{* * *}$ & $-2.56 \mathrm{E}-06^{* * *}$ & $3.62 \mathrm{E}-07$ & $2.80 \mathrm{E}-06^{* * *}$ & -0.0013 \\
\hline sterrors & $1.40 \mathrm{E}-05$ & $7.43 \mathrm{E}-07$ & $4.29 \mathrm{E}-07$ & $7.85 \mathrm{E}-07$ & 0.0009 \\
\hline PROFITABILITY & $-8.13 \mathrm{E}-08^{* * *}$ & $7.11 \mathrm{E}-09^{* * *}$ & $2.71 \mathrm{E}-09^{* * *}$ & $-1.79 \mathrm{E}-09$ & $2.87 \mathrm{E}-06$ \\
\hline sterrors & $2.83 \mathrm{E}-08$ & $1.40 \mathrm{E}-09$ & $9.67 \mathrm{E}-10$ & $2.19 \mathrm{E}-09$ & $1.83 \mathrm{E}-06$ \\
\hline SIZE & $1.48 \mathrm{E}-05^{* * *}$ & $6.72 \mathrm{E}-06^{* * *}$ & $1.05 \mathrm{E}-05^{* * *}$ & $9.87 \mathrm{E}-06^{* * *}$ & $8.58 \mathrm{E}-05^{* * *}$ \\
\hline sterrors & $1.72 \mathrm{E}-06$ & $1.48 \mathrm{E}-06$ & $1.30 \mathrm{E}-06$ & $2.39 \mathrm{E}-06$ & $1.67 \mathrm{E}-05$ \\
\hline GROWTH & $2.61 \mathrm{E}-05$ & $-4.37 \mathrm{E}-05^{* * *}$ & $-4.09 \mathrm{E}-05^{* * *}$ & $-3.89 \mathrm{E}-05^{* * *}$ & -0.0023 \\
\hline sterrors & $3.67 \mathrm{E}-05$ & $8.80 \mathrm{E}-07$ & $5.05 \mathrm{E}-07$ & $5.37 \mathrm{E}-07$ & 0.0443 \\
\hline INVESTMENTS & $-0.0089^{* * *}$ & $-0.0322^{* * *}$ & $-0.0303^{* * *}$ & $-0.0166^{* * *}$ & $-0.0582^{* * *}$ \\
\hline sterrors & 0.0011 & 0.0010 & 0.0005 & 0.0010 & 0.0094 \\
\hline INFLATION & $0.0024^{* * *}$ & $0.0004^{* * *}$ & $-0.0006^{* * *}$ & $-0.0015^{* * *}$ & $-0.0068^{* * *}$ \\
\hline sterrors & $8.60 \mathrm{E}-05$ & $7.46 \mathrm{E}-05$ & $4.23 \mathrm{E}-05$ & $5.92 \mathrm{E}-05$ & 0.0004 \\
\hline GDPRATE & $0.0004^{* * *}$ & $-0.0003^{* * *}$ & $-0.0004^{* * *}$ & $-0.0005^{* * *}$ & $-0.0025^{* * *}$ \\
\hline sterrors & $9.02 \mathrm{E}-05$ & $7.26 \mathrm{E}-05$ & $3.49 \mathrm{E}-05$ & $6.50 \mathrm{E}-05$ & 0.0003 \\
\hline FIXED_EFFECTS & $0.5706^{* * *}$ & $0.9224^{* * *}$ & $1.0112^{* * *}$ & $1.2272^{* * *}$ & $1.3335^{* * *}$ \\
\hline R-squared & $11.5 \%$ & $38.5 \%$ & $45.6 \%$ & $44.2 \%$ & $34.2 \%$ \\
\hline
\end{tabular}

Growth (LGR), enters with a positive sign and from 0.35 quantile becomes negative until the 0.95 quantile and it is statistically significant for majority of quantiles. Firms with higher growth opportunities are more likely to seek external financing. Profitability (Lprof), appears with a negative sign for 0.15 and 0.50 quantile and it is significant from 0.15 until 0.50 quantiles; this fact indicates that higher total-leveraged firms in US according to the Trade-off theory, are less profitable. Total-leveraged firms according to Pecking order theory, regarding their financing decisions follow a preference for internal over external financing and for debt over equity. Non-debt-tax-shields enters with positive and significant sign and remains negative and for 0.35 and 0.95 is negative. This suggests that the relative advantage of resorting to debt as a tax shield alternative to depreciation is lower for median and high levels of leverage. The inflation (infl) starts with a positive sign and from 0.50 quantile becomes negative, which indicates that the high-leveraged firms are influenced from inflation in contrast to leveraged and less-leveraged firms, Frank and Goyal (2009). Liquidity remains with negative and 
significant sign. Cash-rich companies expected to have lower debt and they prefer internal financing (Pecking order theory).

Table 5. Quantile regression in speed of adjustment for quantiles $0.15,0.35,0.5,0.75,0.95$

$$
\begin{aligned}
& \mathrm{LEVB}_{\mathrm{i}, \mathrm{t}}-\mathrm{LEVB}_{\mathrm{i}, \mathrm{t}-1}=\delta *\left(\mathrm{LEVB}_{\mathrm{i}, \mathrm{t}}-\mathrm{LEVB}_{\mathrm{i}, \mathrm{t}-1}\right)+\varepsilon_{\mathrm{i}, \mathrm{t}} \\
& \mathrm{LEVM}_{\mathrm{i}, \mathrm{t}}-\mathrm{LEVM}_{\mathrm{i}, \mathrm{t}-1}=\delta *\left(\mathrm{LEVM}_{*_{\mathrm{i}, \mathrm{t}}}-\mathrm{LEVM}_{\mathrm{i}, \mathrm{t}-1}\right)+\varepsilon_{\mathrm{i}, \mathrm{t}}
\end{aligned}
$$

\begin{tabular}{|l|l|l|l|l|l|}
\hline & \multicolumn{4}{l}{ QUANTILES } \\
\hline & 0.15 & 0.35 & 0.5 & 0.75 & 0.95 \\
\hline SPEED MARKET & $52.7 \%$ & $59.7 \%$ & $81.2 \%$ & $74.2 \%$ & $33.2 \%$ \\
\hline R-squared & $43.6 \%$ & $49.1 \%$ & $63.6 \%$ & $55.9 \%$ & $20.8 \%$ \\
\hline SPEED BOOK & $25.9 \%$ & $49.3 \%$ & $53.2 \%$ & $44.4 \%$ & $7.4 \%$ \\
\hline R-squared & $13.7 \%$ & $27.1 \%$ & $29.4 \%$ & $25.2 \%$ & $4.5 \%$ \\
\hline
\end{tabular}

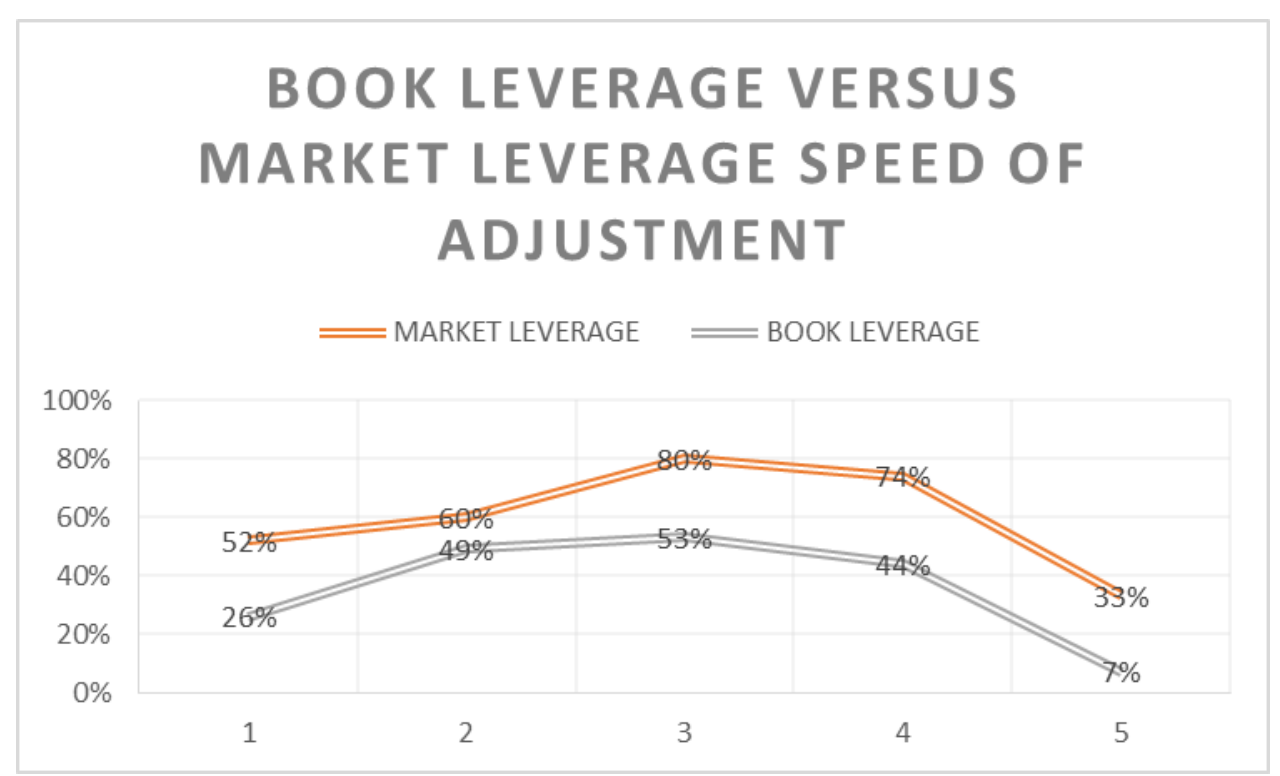

Figure 1. Book Leverage versus Market Leverage

In this graph we observe the percentage of Book and Market leverage speed that is adjusted to each quantile.

\section{Conclusion}

Inspired by the importance of understanding capital structure, this paper uses quantile regression approximations to add to empirical information and focuses on how capital structure relations fluctuate between firms at different stages of the total debt, short-terms debt and long-terms debt distribution. Our findings complement a new dimension to the knowledge of US firms' financing behavior reported in existing literature suggesting that research on the relation between capital structure and incentives could benefit from knowledge of heterogeneity in the capital structure and from using quantile regression techniques in the field of corporate finance. Moreover, if firms maximize subject to an upper constraint on debt, the relationship between leverage and its determinants might change sign as leverage increases, and quantile regression enables us to identify such effects within sample. The adjustment speed slows down for long-terms debt ratio, the adjustment speed slows down only in the first quantile and from the second quantile does not change. The adjustment speed for long-terms debt ratio does not affect during crisis and the total debt ratio slows down for most of the quantiles. 


\section{References}

Ahmed, S. N., \& Wang, Z. (2011). Determinants of capital structure. Managerial Finance, 37(2), 117-133. https://doi.org/10.1108/03074351111103668

Ahsan, T., \& Qureshi, M. A. (2017). The impact of financial liberalization on capital structure adjustment in Pakistan: a doubly censored modelling. Applied Economics, 49(41), 4148-4160. https://doi.org/10.1080/00036846.2016.1276276

Al-Ajmi, J., Abo Hussain, H., \& Al-Saleh, N. (2009). Clients of conventional and Islamic banks in Bahrain. International Journal of Social Economics, 36(11), 1086-1112. https://doi.org/10.1108/03068290910992642

Balios, D., Daskalakis, N., Eriotis, N., \& Vasiliou, D. (2016). SMEs capital structure determinants during severe economic crisis: The case of Greece. Cogent Economics \& Finance, 4(1). https://doi.org/10.1080/23322039.2016.1145535

Baum, C. F., \& Zerilli, P. (2016). Jumps and stochastic volatility in crude oil futures prices using conditional moments of integrated volatility. Energy Economics, 53, 175-181. https://doi.org/10.1016/j.eneco.2014.10.007

Baum, C. F., Caglayan, M., \& Talavera, O. (2016). R\&amp;D Expenditures and Geographical Sales Diversification. The Manchester School, 84(2), 197-221. https://doi.org/10.1111/manc.12092

Beck, T., Demirgüç-Kunt, A., \& Maksimovic, V. (2008). Financing patterns around the world: Are small firms different? Journal of Financial Economics, 89(3), 467-487. https://doi.org/10.1016/j.jfineco.2007.10.005

Bradley, M., Jarrell, G. A., \& Kim, E. H. (1984). On the Existence of an Optimal Capital Structure: Theory and Evidence. The Journal of Finance, 39(3), 857-878. https://doi.org/10.1111/j.1540-6261.1984.tb03680.x

Buchinsky, M. (1994). Changes in the U.S. Wage Structure 1963-1987: Application of Quantile Regression. Econometrica, 62(2), 405. https://doi.org/10.2307/2951618

Buchinsky, M. (1995). Estimating the asymptotic covariance matrix for quantile regression models a Monte Carlo study. Journal of Econometrics, 68(2), 303-338. https://doi.org/10.1016/0304-4076(94)01652-G

Buus, T. (2014). A General Free Cash Flow Theory of Capital Structure. Journal of Business Economics and Management, 16(3), 675-695. https://doi.org/10.3846/16111699.2013.770787

Cook, D. O., \& Tang, T. (2010). Macroeconomic conditions and capital structure adjustment speed. Journal of Corporate Finance, 16(1), 73-87. https://doi.org/10.1016/j.jcorpfin.2009.02.003

Cressy, R., \& Olofsson, C. (1997). European SME Financing: An Overview. Small Business Economics, 9(2), 87-96. https://doi.org/10.1023/A:1007921004599

Črnigoj, M., \& Mramor, D. (2009). Determinants of Capital Structure in Emerging European Economies: Evidence from Slovenian Firms. Emerging Markets Finance and Trade, 45(1), 72-89. https://doi.org/10.2753/REE1540-496X450105

Daskalakis, N., \& Psillaki, M. (2008). Do country or firm factors explain capital structure? Evidence from SMEs in France and Greece. Applied Financial Economics, 18(2), 87-97. https://doi.org/10.1080/09603100601018864

Daskalakis, N., Balios, D., \& Dalla, V. (2017). The behaviour of SMEs' capital structure determinants in different macroeconomic states. Journal of Corporate Finance, 46, 248-260. https://doi.org/10.1016/j.jcorpfin.2017.07.005

De Jong, A., Kabir, R., \& Nguyen, T. T. (2008). Capital structure around the world: The roles of firm- and country-specific determinants. Journal of Banking \& Finance, 32(9), 1954-1969. https://doi.org/10.1016/j.jbankfin.2007.12.034

Dias Basto, D., Nakamura, W. T., \& Basso, L. C. (2009). Determinants of Capital Structure of Publicly-Traded Companies in Latin America: The Role of Institutional and Macroeconomics Factors. SSRN Electronic Journal. https://doi.org/10.2139/ssrn.1365987

Drobetz, W., \& Wanzenried, G. (2006). What determines the speed of adjustment to the target capital structure? Applied Financial Economics, 16(13), 941-958. https://doi.org/10.1080/09603100500426358

EBSCOhost | 46982641 | Determinants of Capital Structure: Experience of Indian Cotton Textile Industry. (n.d.). Retrieved August 18, 2018, from https://web.b.ebscohost.com/abstract?direct=true \&profile=ehost\&scope=site \&authtype=crawler $\& j \mathrm{jnl}=0973$ 
1954\&asa $=$ Y\&AN=46982641\&h=ezG2jZU6fJ1 piPWufk3\%2BOVhPOTrmfk84OUih7qXqU0c6GBqrSyy1 Zzoyc8zLjXIWooz2OgT7si1wtypcfpoz6g\%3D\%3D\&crl=c\&resultNs=AdminWebAuth\&resultL

Frank, M. Z., \& Goyal, V. K. (2009). Capital Structure Decisions: Which Factors Are Reliably Important? Financial Management, 38(1), 1-37. https://doi.org/10.1111/j.1755-053X.2009.01026.x

Friend, I., \& Lang, L. H. P. (1988). An Empirical Test of the Impact of Managerial Self-Interest on Corporate Capital Structure. The Journal of Finance, 43(2), 271-281. https://doi.org/10.1111/j.1540-6261.1988.tb03938.x

Gertler, M., \& Gilchrist, S. (1993). The cyclical behavior of short-term business lending: Implications for financial propagation mechanisms. European Economic Review, 37(2-3), 623631. https://doi.org/10.1016/0014-2921(93)90052-C

Gertler, M., \& Gilchrist, S. (1993). The Role of Credit Market Imperfections in the Monetary Transmission Mechanism: Arguments and Evidence. The Scandinavian Journal of Economics, 95(1), 43. https://doi.org/10.2307/3440134

Hackbarth, D., Miao, J., \& Morellec, E. (2006). Capital structure, credit risk, and macroeconomic conditions. Journal of Financial Economics, 82(3), 519-550. https://doi.org/10.2307/3440134

Hanousek, J., Kočenda, E., \& Maurel, M. (2011). Direct and indirect effects of FDI in emerging European markets: A survey and meta-analysis. Economic Systems, 35(3), 301-322.

https://doi.org/10.1016/j.ecosys.2010.11.006

Hasbrouck, J. (1988). Trades, quotes, inventories, and information. Journal of Financial Economics, 22(2), 229-252. https://doi.org/10.1016/0304-405X(88)90070-0

Institute of Southeast Asian Studies. Asean Economic Research Unit., T. D. K., \& Ramachandran, N. (1984). ASEAN economic bulletin. ASEAN Economic Bulletin (Vol. 23). Institute of Southeast Asian Studies, ASEAN Economic Research Unit. Retrieved from https://muse.jhu.edu/article/209201/summary

JAI Press, I. (1991). The Journal of entrepreneurial and small business finance. Journal of Small Business Finance (Vol. 1). JAI Press. Retrieved from https://www.econstor.eu/handle/10419/114623

JENSEN, M. C. (1993). The Modern Industrial Revolution, Exit, and the Failure of Internal Control Systems. The Journal of Finance, 48(3), 831-880. https://doi.org/10.1111/j.1540-6261.1993.tb04022.x

Kaloudis, A., \& Tsolis, D. (2018). Capital structure in U.S., a quantile regression approach with macroeconomic impacts. Journal of Economics Bibliography, 5(1), 1-17.

Karadeniz, E., Yilmaz Kandir, S., Balcilar, M., \& Beyazit Onal, Y. (2009). Determinants of capital structure: evidence from Turkish lodging companies. International Journal of Contemporary Hospitality Management, 21(5), 594-609. https://doi.org/10.1108/09596110910967827

Kayo, E. K., \& Kimura, H. (2011). Hierarchical determinants of capital structure. Journal of Banking \& Finance, 35(2), 358-371. https://doi.org/10.1016/j.jbankfin.2010.08.015

Koenker, R. (2004). Quantile regression for longitudinal data. Journal of Multivariate Analysis, 91(1), 74-89. https://doi.org/10.1016/j.jmva.2004.05.006

Koenker, R., \& Bassett, G. (1978). Regression Quantiles. Econometrica, 46(1), 33. https://doi.org/10.2307/1913643

Korajczyk, R. A., \& Levy, A. (2003). Capital structure choice: macroeconomic conditions and financial constraints. Journal of Financial Economics, 68(1), 75-109. https://doi.org/10.1016/S0304-405X(02)00249-0

Lemmon, M. L., \& Zender, J. F. (2010). Debt Capacity and Tests of Capital Structure Theories. Journal of Financial and Quantitative Analysis, 45(05), 1161-1187. https://doi.org/10.1017/S0022109010000499

Marsh, P. (1982). The Choice Between Equity and Debt: An Empirical Study. The Journal of Finance, 37(1), 121-144. https://doi.org/10.1111/j.1540-6261.1982.tb01099.x

Michaelas, N., Chittenden, F., \& Poutziouris, P. (1999). Financial Policy and Capital Structure Choice in U.K. SMEs: Empirical Evidence from Company Panel Data. Small Business Economics, 12(2), 113-130. https://doi.org/10.1023/A:1008010724051

Muthama, C., Mbaluka, P., \& Kalunda, E. (2013). An Empirical Analysis of Macro-Economic Influences on Corporate Capital Structure of Listed Companies in Kenya. Journal of Finance and Investment Analysis 
(Vol. 2). online) Scienpress Ltd. Retrieved from http://www.scienpress.com/Upload/JFIA/Vol 2_2_3.pdf

Öztekin, Ö., \& Flannery, M. J. (2012). Institutional determinants of capital structure adjustment speeds. Journal of Financial Economics, 103(1), 88-112. https://doi.org/10.1016/j.jineco.2011.08.014

Powell, J. L. (1984). Least absolute deviations estimation for the censored regression model. Journal of Econometrics, 25(3), 303-325. https://doi.org/10.1016/0304-4076(84)90004-6

Powell, J. L. (1986). Censored regression quantiles. Journal of Econometrics, 32(1), 143-155. https://doi.org/10.1016/0304-4076(86)90016-3

Psillaki, M., \& Daskalakis, N. (2009). Are the determinants of capital structure country or firm specific? Small Business Economics, 33(3), 319-333. https://doi.org/10.1007/s11187-008-9103-4

Rajan, R. G., \& Zingales, L. (1995). What Do We Know about Capital Structure? Some Evidence from International Data. The Journal of Finance, 50(5), 1421-1460. https://doi.org/10.1111/j.1540-6261.1995.tb05184.x

Rao, S., Li, M., \& Canada, S. (2010). Sensitivity of Capital Stock and Multifactor Productivity Estimates to Depreciation Assumptions: A Canada-U.S. Comparison. Retrieved from https://www.researchgate.net/publication/227580096

Serrasqueiro, Z., \& Caetano, A. (2014). Trade-Off Theory Versus Pecking Order Theory: Capital Structure Decisions In A Peripheral Region Of Portugal. Journal of Business Economics and Management, 16(2), 445-466. https://doi.org/10.3846/16111699.2012.744344

Torres, O., \& Julien, P. A. (2005). Specificity and Denaturing of Small Business. International Small Business Journal, 23(4), 355-377. https://doi.org/10.1177/0266242605054049

\section{Copyrights}

Copyright for this article is retained by the author(s), with first publication rights granted to the journal.

This is an open-access article distributed under the terms and conditions of the Creative Commons Attribution license (http://creativecommons.org/licenses/by/4.0/). 